\section{Higher learning}

Richard Davenport-Hines

Medieval and Early Renalssance Medlcine. An Introduction to Knowledge and Practice. By Nancy G. Siraisi. Chicago University Press: 1990. Pp. 250. Hbk $\$ 37.50, £ 29.95$; pbk \$10.95, £8. 75 .

THE realities of health and disease, the needs of patients and their experiences at the hands of medical practitioners cannot fail to make interesting reading. Physicians are in intimate contact with their patients at the great human crises of birth and death, and the story of their professional lives is always rich in human significance. Yet given the promising subject of her book, Nancy Siraisi's study of mediaeval medical practices in western Europe is strangely disappointing. The tone of her monograph is unnecessarily desiccated and, except in her more lively chapter on surgical techniques, gives little sense of the human lives which she is chronicling.

Siraisi begins by tracing the dominant influences of ptolemaic astronomy, aristotelian logic, epistemology, cosmology and physics on the conceptualization and practice of medicine in the four centuries before 1500 . She traces the ancient and Islamic antecedents of west European

\section{New in paperback}

- Lemurs of the Lost World, by Jane Wilson, describes the zoological wealth of the caves and forests of northern Madagascar. Published by Harrap, price is $£ 5.95$.

- New in paperback is Hamiltonian Systems: Chaos and Quantization by Alfredo M. Ozorio de Almeida. First published as a Cambridge Monograph on Mathematical Physics in 1988. the paperback costs $£ 15, \$ 24.95$

- The Crisis of Life on Earth is a science journ. alist's account of "how natural forces and human folly have combined to bring our planet to the edge of an apocalypse". By Tim Radford, formerly science editor of the Guardian news. paper, publisher is Thorsons, price £6.99.

- The latest in the IRL Press 'Practical Approach' series is Receptor Biochemistry, edited by E. C. Hulme. The book is the first in a set of three covering receptor-effector coupling and neurotransmitter/hormone receptorligand interactions. Publisher is Oxford University Press, price is $£ 25$. (Also available spiral bound at $£ 35$.)

- Penguin books has just published Galileo: Heretic by Pietro Redondi. The first English edition was published by Princeton University Press in 1987, and the book was reviewed in Nature that year $(\mathbf{3 3 0}, 617)$. The paperback price is $£ 7.99$.

- Biotechnology in the Food Industry by M. P Tombs is published by the Open University Press in association with the Institute of Biology. The book is for undergraduates and postgraduates, and the author aims to point out the benefits and the drawbacks of this controversial subject. Price 114.99 . (Also published in hardback at $£ 35$.) medical ideas, showing the continuing importance of hippocratic authors and the galenic system. The gradual multiplication of medical books and their accumulation in monasteries and later universities steadily increased the theoretical, systematic and learned elements in medicine until a rich, specialised literature had developed. Beginning in Salerno, medicine became a part of university curricula about physicians' status and emoluments. The criticism of the better-educated mediaeval physicians that they are pursuing for mercenary motives subjects that should be studied out of charity or for love of pure knowledge will be familiar to many contemporary readers. The ways in which christianization resulted in new centres of healing (with monks turning some monasteries into medical centres),
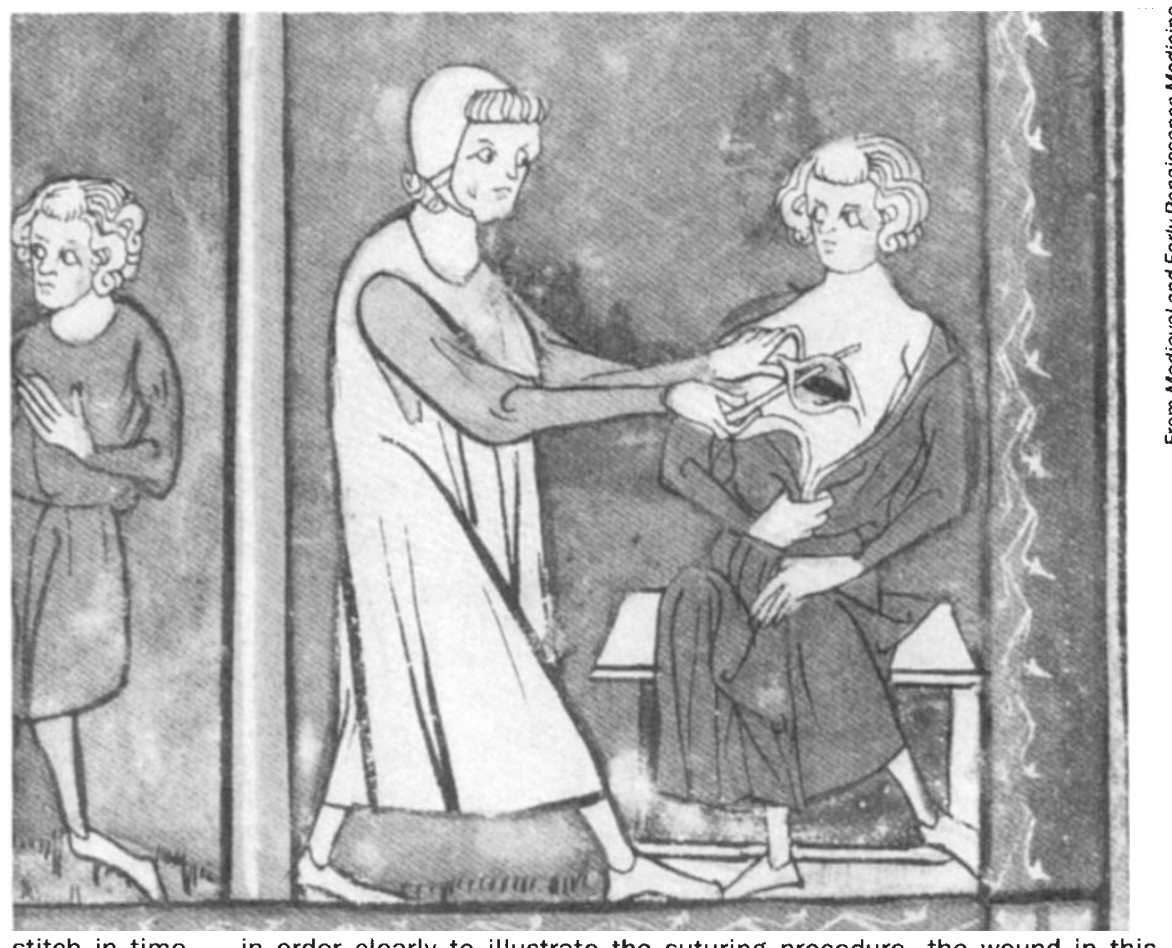

A stitch in time - in order clearly to illustrate the suturing procedure, the wound in this fourteenth-century miniature has been greatly exaggerated.

and, as shown by the life of the fifteenthcentury literary humanist and medical practitioner Michele Savonarola, the subject was accepted as one of the higher branches of learning. Siraisi describes the extent of physiological and anatomical knowledge and surgical techniques, and other treatments such as phlebotomy, blood-letting and herbalism. She also shows the primacy in mediaeval medical theory of belief in the four humours, and in the use of concept of complexion to identify the different elements of the human body - a set of beliefs which were finally shaken by the epidemic of syphilis in the $1490 \mathrm{~s}$.

Some of the most successful passages of her book concern questions of professional identity. The gradual professionalization of medical practice, the contrasts between lettered practitioners in rich, urban areas and lowly empirics in poor, rural districts, the ways in which medical specialization became a mark of low status in practitioners, the employment by mediaeval municipalities of distinguished medical men, the persistent sub-cultures of women surgeons and of Jewish physicians - these historical developments are all discussed, in ways which recall many familiar twentieth-century controversies and the interplay between ideas of healing and faith, or evil and disease, are solidly but not searchingly described.

Although Siraisi's book is offered as a resumé of current historical understanding and makes little pretence of offering ambitious or original insights for specialist scholars, some sections are abstruse and will make taxing reading for the nonspecialist. There is a tendency for truisms to be enunciated with ponderous importance as if they are astonishing new insights, as for example when readers are allowed to share Siraisi's dazzling realization that a talent for prognosis "was an important aspect of the physician's skill". Some compensation for the laboured prose is given by many excellent black and white illustrations of medical techniques taken from mediaeval or Renaissance treatises or manuscripts. These are informatively captioned, and provide a fascinating sense of medical iconography in a pre-literate society. Overall, Medieval and Early Renaissance Medicine is a reliable but very far from inspired general introduction to its subject.

Richard Davenport-Hines, 51 Elsham Road, London W14 8HD, UK is a freelance medical historian. 